\title{
Promoting reading skills or wasting time? Students' perceived benefits of reading in an intermediary programme at the Vaal University of Technology
}

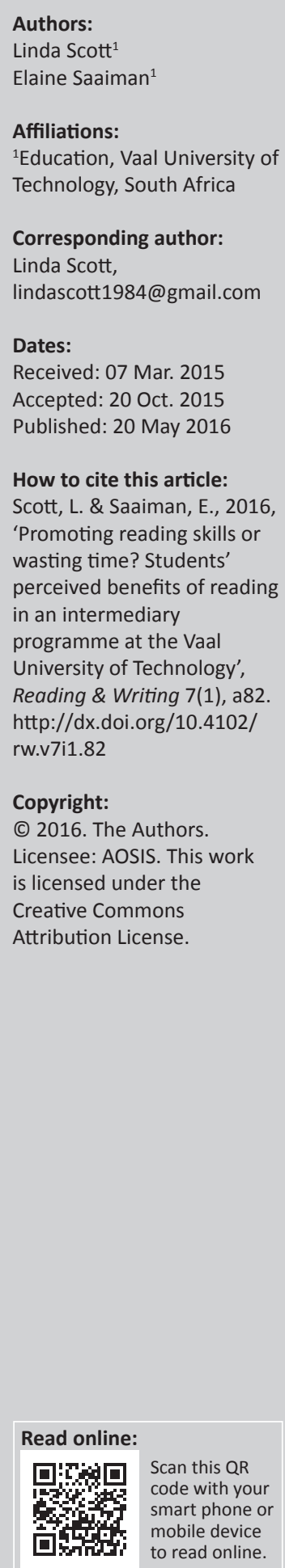

Notwithstanding the substantial transformation of education in South Africa in the last 20 years, specifically to redress the past inequalities, the challenges are ongoing. These challenges include tertiary institutions having to accommodate a culturally and linguistically diverse group of students, often second-language (L2) English speakers, in an English lingua franca classroom. This study investigated the reading attitudes and habits of students in an intermediary programme of a tertiary institution and any perceived changes to these attitudes or habits, as well as their perceptions of the promotion of reading by the programme. On successful completion of the intermediary programme, students register for the compulsory first-year English distance learning course and are required to complete a placement test. Results for students who attended the intermediary programme were compared with those of students who did not attend the intermediary programme but registered directly for mainstream. The teaching of reading appeared invaluable at the tertiary level with the indication that students' attitudes and behaviour changed and that they inter alia realised the academic value thereof, made decisions to take up reading as a hobby and discovered new genres.

\section{Introduction}

Education in South Africa, and more specifically tertiary education, continues to face challenges. Sutherland (2009:4) states that the South African government has addressed the inequalities perpetuated during the apartheid era and continues to work on closing the gap that was created. Problems in education are widespread, and students enrolling in the University of South Africa require additional support to enable them to succeed in their studies (Maphosa 2014:11). Van Rooy and Coetzee-Van Rooy (2015) emphasise the fact that language is regarded as one of the most important issues contributing to the poor academic performance of students at South African universities.

Many researchers have highlighted the importance of reading in an academic context. Palani (2012:91) states that ' $[e]$ ffective reading is the most important avenue of effective learning' and the achievement of academic success requires successful reading. Abramson (2004) states that ' $[b]$ eing a good reader is not a luxury in the 21st century. It is a necessary life skill'. He believes that means more than just being able to enjoy the latest biography written by an iconic public figure or reading your favourite authors' newest murder mystery novel. It means being able to understand the lease agreement of your new house, the terms and conditions of your credit card and instructions for installing new software on your computer (Abramson 2004). Many definitions have been suggested for reading, including '[ $r$ ]eading is a complex information processing skill in which the readers interact with the text in order to create meaningful discourse' (Akarsu \& Harputlu 2014:61). Tien (2015) posits that extensive reading is essential for the enhancement of readings skills and acquisition of knowledge. Therefore, reading is an indispensable skill; it is also fundamentally interrelated to the process of education and to students achieving educational success.

Sutherland (2009:14) states that because of the lack of skills in students, there has been a need to implement programmes in higher education (HE) institutions to bring HE to students who otherwise would not have had access to these institutions. These skills include communication, reading, listening, life and numeric skills. A challenge faced by HE is that there has been a shift 
towards a supply-oriented view with a demand for new knowledge and skills (Bodendorf \& Swain 2001). HE institutions need to consider this factor when developing their curriculum and ensure they provide education that meets the needs of job markets. This has led to the implementation of programmes that aim to address deficiencies in the skills of students and provide them with the tools for academic success, such as the intermediary programme at the Vaal University of Technology (VUT).

According to Sutherland (2009:5), the learning area of language literacy and communication comprises the teaching of language, which in turn underscores the skills of reading, listening and observing. The focus of the intermediary programme at VUT is two-fold. Firstly, it aims to develop skills in students, which they require to perform well in an institution of HE and increase their chances of achieving academic success. Secondly, to provide students alternative admission to HE by giving them the opportunity to increase their academic performance levels, bringing them in line with academic admission requirements to the university (Sutherland 2009:14).

This study aims to evaluate the students' attitudes towards the reading module of the language literacy course of the intermediary programme and their perceptions of the benefits in the enhancement of reading skills. It is conducted to answer the research question: Do the students who are enrolled in the intermediary programme at VUT perceive the reading module as promoting reading skills or wasting time.

\section{Theoretical framework}

The activity of reading is demanding for the reader, and in the last 20 years, researchers have investigated the motivations for reading (Seitz 2010), which are multidimensional and include the following components: self-efficacy, interest, preference for challenge and social interaction. A central factor affecting reading performance is the attitude of the student. Seitz (2010:31) suggests that ' $[r]$ ecurring failures to succeed and self-concept issues often complicate a student's ability to learn any of a variety of reading skills'. Reading attitude can be altered by rebuilding damaged self-concepts, and the reading module of the intermediary programme at VUT focuses on encouraging the student to develop reading skills in an attempt to uplift students' self-concepts and change their attitudes towards reading.

It is important not to underestimate the role of reading in academics and its influence on learning. Researchers have highlighted the value of developing reading skills and the benefits of reading, but the studies have moved towards stressing students' positive attitudes and motivations towards reading (Tien 2015). Students who have difficulty reading may develop a lifelong aversion towards reading (Seitz 2010), and history and experience appear to influence reading attitudes (Lukhele 2013).

\section{The advantages of reading}

Reading is one of the most important academic tasks for any student. In fact, it can be argued that reading is the essence of all formal education as 'literacy in academic settings exists within the content of a massive amount of print information' (Grabe 1991:389) and students primarily access this information through reading. Literacy is much more than just being able to read or write, it includes being able to make sense of the text and find a purpose in the text. Butler (2013:72) states that '[o]ne of the critical focuses of students' under preparedness is their levels of academic literacy (AL) in the language of learning at South African universities (mainly English or Afrikaans)' . AL is more than just reading and writing in the academic context. There is no single all-encompassing definition for AL, and this could be because it is difficult to agree upon a single definition when the field of ALencompasses so many sub-disciplines ranging from sociolinguistics, text editing, lexicography, writing and language testing (Butler 2013). The literature provides generic definitions for AL, which many intervention programmes follow, such as Weideman (2003) who states that AL includes being able to access, process and produce academic literature. Literacy programmes should focus on enhancing student understanding of discourse practices within academia and curriculum design for these programmes should focus on developing the abilities of students reading, writing, speaking, listening and research skills (Papashane \& Hlalele 2014).

In HE institutions, students are exposed to a number of texts and textbooks that require independent reading. Students are expected to comprehend what they read in order for them to successfully analyse, evaluate, synthesise and critique on the information from various sources (Bharuthram 2012). Even though many students will have the ability to decode texts (translating the printed word into a sound) when they reach the tertiary level, they are unable to understand what they have decoded; this means they lack comprehension skills. Therefore, the teaching of reading strategies is vital for students to improve their reading comprehension and enhancing their chances of academic success (Bharuthram 2012).

The ability to read is acknowledged as the most stable and durable of the second-language (L2) modalities (Bernhardt 1991), which means that reading plays a vital role in acquiring a L2. South Africa has 11 official languages and the majority of universities have opted for English lingua franca classrooms. This usually means that the majority of students have classes in their second or third language. Students should at all times be encouraged to read not only prescribed books but also self-selected books that consist of large amounts of meaningful language that will assist in improving their L2. Willis, Stephens and Matthew (1996:8) believe that '[ $r$ ]eading widely is one of the best ways to learn another language' but this could also include improving the reading skills.

One of the key benefits of reading lies in its power to impart new vocabulary to students. This is evident in the numerous studies conducted over the years in schools and universities 
(Pitts, White, \& Krashen 1989; Day, Omura \& Hiramatsu 1991; Hulstijn 1992; Palani 2012; Tien 2015). Generally, the studies confirm that learners can and do acquire new word knowledge incidentally through comprehension-focused reading in an L2. In support of this notion, it is safe to assume that by increasing vocabulary knowledge, the level of more accurate spelling and correct grammar utilisation is automatically improved.

Reading builds knowledge of various kinds (inter alia world knowledge) to use in various forms of writing, and writing merges knowledge in a way that builds schema to read with (Bereiter \& Scardamalia 1987; Sternglass 1988; Pretorius 2000). The development of good reading habits and skills improve students' ability to write. In fact, reading within a discipline helps students to write professionally in their field, as Carson and Leki (1993) posit that scholars of biology should write articles the way biology professors do by reading articles that biology professors have written. Reading in a specific field of study will ensure that students become proficient in their subjects.

Pretorius (2002:189) explains that students with reading problems are caught in a 'negative cycle of failed reading outcomes and academic underperformances'. This can be avoided if the main objective of the educator is to expand on students' language skills in order for them to become better communicators in their chosen disciplines. As Bamford and Day (1997:7) state, 'until students read in quantity, they will not become fluent readers'.

\section{Reading and life skills}

Linguists and language educators recognise the four basic literacy skills as listening, speaking, reading and writing (Kolawole 2009). These skills are valued as life skills because they enable the people to both receive messages and express themselves. In the present globalised world, where so much depends on the skills of reading and writing, it is essential for reading skills to be developed. A good student requires good reading skills because in order to learn they need to be able to read. Pretorius (2000) views reading skills as a 'powerful learning tool', and not mastering this skill will lead to the students being hampered in their quest for success. The importance of reading cannot be denied; it is a vital skill for achieving academic success at tertiary-level education (Akabuike 2012:247).

Robatjazi (2008) states that people with different languages and cultures are brought into contact with each other, leading to the development of foreign language education. This globalisation and the challenges presented by the contemporary world lead to a need not only for proficient intercultural interlocutors but also for second- and thirdlanguage students to improve on their language skills and reading. However, L2 learners face a number of problems when it comes to reading.

\section{Reading and L2 learners}

Pretorius (2002:170) believes that the reading situation in South Africa has reached a point of crises, and Palani (2012) reiterates this by stating that promoting reading habits is essential for the creation of a literate society and the presence of mass media hampers an interest in books, magazines and journals. Carter (2010:5) believes the reading problems experienced in South Africa could be ascribed to the 'detrimental effects of the apartheid regime'. Many students who are attending first year at university and who are nonnative English speakers feel ill at ease when English is the medium of instruction (Kannan 2009).

In a study of Turkish students in the Netherlands, Droop and Verhoeven (2003:78) posit that there is very little attention given to the first language of ethnic minorities and they are 'totally immersed in a second language (L2) reading curriculum'. A similar situation exists in South African schools where English and Afrikaans are the lingua franca of the classroom for the majority of the students' school years.

Difficulties with reading comprehension could significantly impact the dropout rate of students in schools and universities. In the USA and Europe, there is a higher rate of dropout for L2 learners than for their monolingual first-language counterparts, and a study in 2009 indicated that the United States had a $21 \%$ dropout rate for foreign-born students (Melby-Lervåg \& Lervåg 2013:409). Pretorius (2000) refers to the underperformance of students at all levels in South African schools. The medium of instruction is their L2 and this is a cause for concern. Other factors that could contribute to this include disadvantaged students who do not come from sociocultural communities that support reading and a lack of support for reading problems encountered by L2 learners (Pretorius 2000). Often, a student experiences reading problems at an early age and these problems continue throughout the student's school career leading to a dislike of reading. This is highlighted as the Matthew's effect where it can be observed that the reading skills of a student who is a slow starter progressively decline and the gap widens between the slow starters and fast starters (Stanovich 1986). By the time students reach $\mathrm{HE}$, they fall far behind their better reading peers because of a lack of reading skills.

\section{University students and reading: reading supports academic achievement}

There can never be enough emphasis placed on the role and importance of the English reading in the attainment of education through communication abilities, specifically in South African HE institutions and the English lingua franca classroom (Aina, Ogundele \& Olanipekun 2013:355). HE requires students to spend large amounts of time in reading to gain the required information and knowledge from the content of the prescribed reading material. There is a growing call for universities to take note of the importance of reading, to recognise that most learning takes place through reading the written word and to consider realising the need for university-centred reading programmes (Pretorius 2000). 
Pretorius (2000:46) opines that even though 'language proficiency and reading skills both draw on linguistic knowledge and skills, reading develops specific cognitivelinguistic skills that are not necessarily operative in oral forms of discourse'. As reading for the purposes of learning and for the development of knowledge in the academic institution requires students to be able to make links, understand opinions, research and be able apply this to studies, there appears to be a definite correlation between the level of proficiency in the reading ability in English and the academic performance of students (Aina et al. 2013). A student who is a good reader will perform better academically than his/her lesser skilled peers. According to Pretorius (2000:46), the improvement of reading skills in students will lead to an improvement in the reading levels of the students, leading to better comprehension, understanding and academic achievement.

This study takes cognisance that there are immeasurable benefits to reading, specifically academically. There are problems associated with reading skills, and the ones addressed in this research relate to the use of English lingua franca in a HE institution where the dominant language in the intermediary classes that were researched indicates that the highest percentage of students are first-language Sesotho speakers at $18.55 \%$, followed by isiZulu with $15.35 \%$, a number of lesser percentages for other language, and English speakers lagging behind making up a mere $1.28 \%$ of the total students.

A positive attitude towards reading has been identified as motivation for students to continue reading, and reading has been identified as a tool for academic success. Academic success for students should be the foundation of any programme or curriculum development, and this study investigates the impact of the reading module on the students' attitudes towards reading. This is performed to identify whether there has been a change in the attitudes of students towards reading, their perceptions of the change in reading attitudes and whether they intend to continue reading (see illustration in following paragraph).

A reading module leads to positive attitude $\rightarrow$ Increase in reading and improved reading skills $\rightarrow$ Academic success.

\section{Purpose of the study}

The purpose of the study was to investigate the perceptions of students, attending the VUT intermediary programme, towards the reading module of the programme. This was carried out to determine whether there was a change in their attitudes towards reading. The data were then compared to the results achieved by students for their entrance into the first-year English distance learning (EDL) subject to validate the findings.

\section{Methodology \\ Research methodology}

A literature review on the influence of attitudes towards reading, the advantages of reading, life skills, L2 acquisition and academic achievement was conducted. In addition, both quantitative and qualitative approaches were used to collect data. Walliman (2011:73) recommends the examination of both qualitative and quantitative data when humans are being researched. Data were collected using a combination of questionnaires from participants, and the results achieved by the students in a placement test for the EDLcourse were compared with results of students who had not attended the intermediary programme but were registered directly for the EDL course.

There is a dearth of research on the perception of the student on the benefits of reading (Dreyer \& Kopper 2004; Rimensberger 2014) in an intermediary programme and the current study could contribute to an understanding of the benefits of reading, from the perception of the student, and provide valuable information regarding skills development in HE.

The intermediary programme at VUT continuously addresses problems associated with poor student performance by researching the issues, formulating possible solutions and striving to overcome adversities experienced by the students. The programme aims to:

identify academically talented, but under prepared postsecondary domestic and foreign students from educationally and economically disadvantaged communities ... develop the skills and resources required to obtain a tertiary qualification necessary to pursue a specific career. (Sutherland \& Brits 2009)

The programme is open to all students with a grade 12 National Senior Certificate or an equivalent qualification and applicants are required to meet the predetermined entrance requirements. The programme is interventionary by nature and provides academic support to prospective students to enable them to meet the admission requirements of the university. One of the problems identified by the programme is that students lack adequate reading skills to achieve academic success, and in addition, there is a lack of positive attitude towards reading. The specific reading module referred to in this study is designed to change the reading attitudes of students by motivating and encouraging them to read, which could lead to the achievement of academic success. Students are required to read two novels prescribed by the programme curriculum with the purpose of achieving an in-depth understanding of the novels.

\section{Research design}

According to Wiid and Diggines (2013:54), it is important to implement a well-structured plan in order to ensure that the objectives of a research are addressed. Hair, Bush and Orinau (2008:32) are of the opinion that the objectives of a research study are the factors that serve to guide the researcher on the research design. A self-administered questionnaire comprising both closed- and open-ended questions was developed to address the objective of the study and collect data. In addition, data were also collected to compare the results of a placement test for a first-year 
EDL course of students who completed the intermediary course with those of students who did not complete the intermediary course.

\section{Questionnaire design}

According to Denscombe (2010:157), the design of a questionnaire should be well planned. The questionnaire was designed to identify students' attitudes and perceptions of reading in the intermediary programme. It contained different sections where participants marked the answers using a 4-point Likert-type scale, where 1 = strongly disagree, 2 = disagree, 3 = agree and $4=$ strongly agree.

Section A of the questionnaire dealt with biographical details of the participants (four items), Section B explored the personal reading habits of participants before attending the intermediary programme at VUT (11 items), and Section C questioned the participants' participation in the reading module (11 items). Section D delved into the future reading intentions of participants (12 items). Lastly, Section E required participants to indicate their opinion on a dichotomous scale $(1=$ yes and 2 $=$ no) on whether they believed the intermediary programme developed their reading skills, and they were then required to follow-up stating why it did or did not play a role (two items). This final open-ended question was designed to provide insight into the opinions of participants regarding the development of reading skills by the intermediary programme. The comments made by the participants were examined for similarities and linked in themes for reporting.

\section{Procedures}

The participants were requested to voluntarily stay behind at the end of one of their classes to participate in the study. The researchers handed out the questionnaires to the participants and these questionnaires were handed back to the researchers once completed. A sample size of 565 students was registered for the intermediary programme in various disciplines including information technology, humanities, engineering and management. Of the questionnaires that were distributed, 502 questionnaires were returned, of which 33 were deemed unusable because of missing information and 469 were considered suitable for data analysis.

\section{Ethical considerations}

Ethics in research guide the process of research and refer to the norms or standards (Gupta 2011:21). According to Walliman (2011:43), there are two important aspects to ethical research issues, namely that of the values of the researcher such as honesty and personal integrity and the way the researcher treats the people involved in the research regarding issues such as anonymity, confidentiality and informed consent.

The researchers implemented the following ethical procedures during the data collection process:

- participation was voluntary

- confidentiality and anonymity of participants was assured
- all participants were requested to sign consent forms agreeing to participate in the study

- participants could withdraw from the study at any time without any repercussions (Denscombe 2010:160).

\section{Data analyses}

The data were reported using descriptive statistics for analysis, with frequencies and percentages. Data were uploaded to the Statistical Programme for Social Studies (SPSS), version 15.0, for Windows for analysis.

\section{Validity and reliability}

Walliman (2011:104) refers to internal and external validity where the generalisation of the results should 'reflect the situation in the real world'. External validity is the extent to which findings can be generalised to populations or to other settings (Walliman 2011:104).

The reliability assessment for the study was ascertained by computing the Cronbach's alpha coefficient values, which is known as an internal consistency estimate of the reliability of test scores. According to Nunnally (1978), Cronbach's alpha coefficients of less than 0.50 are deemed unacceptable; those between 0.50 and 0.69 are considered adequate; whereas, those above 0.70 are regarded as acceptable in social science enquiry. The standardised Cronbach's alpha values for Section B and Section D were established at 0.516 and 0.585 , respectively, indicating an adequate level of internal consistency amongst the scale items. A question in each of Sections B and D needed to be deleted because they had a negative effect on the reliability. The Cronbach's alpha values for Section $C$ fell below 0.50 but it was decided to still report on some of the questions in this section, as the results would not have a significant effect on the results of the study.

\section{Results}

\section{Demographics}

Table 1 provides the demographic profile of the study sample. More male students than female students participated in the study. The highest percentage of participants were over 21 years old $(n=154 ; 32.8 \%)$ followed by 20 years old

TABLE 1: Demographic profile of participants.

\begin{tabular}{llcccc}
\hline Variable & & $f$ & $\%$ & Valid \% & Cumulative \% \\
\hline $\begin{array}{llccc}\text { Gender } \\
\text { Valid }\end{array}$ & Male & 252 & 53.7 & 53.7 & 53.7 \\
& Female & 217 & 46.3 & 46.3 & 100 \\
\hline Age & Total & $\mathbf{4 6 9}$ & $\mathbf{1 0 0}$ & $\mathbf{1 0 0}$ & - \\
Valid & 17 & 1 & 0.2 & 0.2 & 0.2 \\
& 18 & 36 & 7.7 & 7.7 & 7.9 \\
& 19 & 134 & 28.6 & 28.6 & 36.5 \\
& 20 & 144 & 30.7 & 30.7 & 67.2 \\
& $21+$ & 154 & 32.8 & 32.8 & 100 \\
\hline & Total & $\mathbf{4 6 9}$ & $\mathbf{1 0 0}$ & $\mathbf{1 0 0}$ & - \\
\hline frequency & & & & &
\end{tabular}

$f$, frequency. 
$(n=144 ; 30.7 \%), 19$ years old $(n=134 ; 28.6 \%), 18$ years old $(n=36 ; 7.7 \%)$ and 17 years old $(n=1 ; 0.2 \%)$.

Figure 1 indicates the language profiles of the participants. It can be noted that the majority of participants do not have English as their first language.

\section{Personal reading habits prior to attending the intermediary programme}

Table 2 indicates that the majority of students (67.6\%) strongly agreed that they understood the importance of reading for achievement in academics before attending the intermediary programme, $25.4 \%$ agreed, $2.6 \%$ disagreed and only $4.3 \%$ strongly disagreed. The majority of participants also stated that they understood that developing reading skills would make them better students.

Questions from Section B regarding the personal reading habits of participants including the participants' reading habits from their school attendance rendered the results in Table 3.

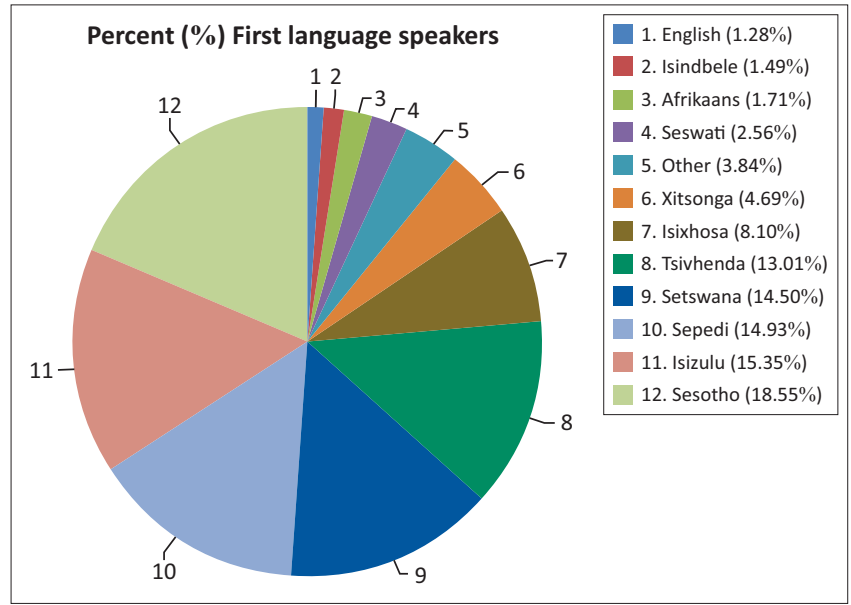

FIGURE 1: Language profiles of participants.
It is deduced that the majority of participants, before enrolling in the intermediary programme, considered reading as a hobby, were members of the local or school library and regularly borrowed books, often read for pleasure and read every book prescribed at their high school. Only 32.6 agreed to having read more than 10 books, whilst $19.6 \%$ strongly agreed, $32.2 \%$ disagreed and $15.6 \%$ strongly disagreed, and only a small number of students (5.1\% agreed and $4.3 \%$ strongly agreed) had never read a book before attending the intermediary programme.

\section{Behaviour of participants during the reading module}

Section C of the questionnaire measured the participants' behaviour during the reading module of the programme. Table 4 sets out the results from the questionnaire of the actions of the students.

It can be observed that the majority of the students read both the novels and only a small percentage did not read both novels. Similarly, only a small percentage said they only read one of the novels. Regarding their enjoyment of the novels, the majority of the participants agreed that they had enjoyed the novels and only a small percentage disagreed.

Therefore, it is evident that more participants read the books prescribed in the intermediary programme than those who read their books at school, as depicted in Figure 2 and Figure 3.

\section{Participants' future intentions}

Section $\mathrm{D}$ of the questionnaire was designed to discover whether the reading patterns and skills of participants had in fact been altered since attending the intermediary programme in order to confirm that skills development occurred. The results are indicated in Table 5.

TABLE 2: Understanding the importance of reading

\begin{tabular}{|c|c|c|c|c|}
\hline Before enrolling at VUT, I & $\%$ Strongly disagree & $\%$ Disagree & $\%$ Agree & $\%$ Strongly agree \\
\hline Believed that reading is important for academic achievement & 4.3 & 2.6 & 25.4 & 67.7 \\
\hline Understood that if I did not have good reading skills I would not be a good student & 6.6 & 9.6 & 40.5 & 43.3 \\
\hline
\end{tabular}

VUT, Vaal University of Technology.

TABLE 3: Personal reading habits.

\begin{tabular}{|c|c|c|c|c|}
\hline Before enrolling at VUT, I & $\%$ Strongly disagree & $\%$ Disagree & $\%$ Agree & $\%$ Strongly agree \\
\hline Considered reading to be a hobby & 7.5 & 26.4 & 49.5 & 16.6 \\
\hline Was a member of the local library or school library and regularly borrowed books & 24.7 & 32.6 & 32.4 & 10.2 \\
\hline Had read more than 10 books & 15.6 & 32.2 & 32.6 & 19.6 \\
\hline Often read for pleasure & 8.7 & 21.5 & 51.6 & 18.1 \\
\hline Read every book prescribed at my high school & 5.3 & 20.9 & 38.4 & 35.4 \\
\hline Had never read a book & 74.8 & 15.6 & 5.1 & 4.3 \\
\hline
\end{tabular}

VUT, Vaal University of Technology.

TABLE 4: Participants' actions regarding reading.

\begin{tabular}{|c|c|c|c|c|}
\hline With reference to the two prescribed novels, ... & $\%$ Strongly disagree & $\%$ Disagree & $\%$ Agree & $\%$ Strongly agree \\
\hline I read both the books that were assigned & 3.6 & 10.4 & 43.3 & 42.6 \\
\hline I only read one of the books that were assigned & 49.9 & 30.7 & 12.4 & 7 \\
\hline I did not enjoy reading the books & 50.7 & 35.6 & 8.5 & 5.1 \\
\hline
\end{tabular}


The questions in Section D attempted to discover the future intentions of participants regarding reading, in order to establish whether a change in behaviour had occurred. When answering whether they have discovered new genres, the majority agreed on this.

As indicated in Table 5, the majority of participants agreed or strongly agreed that they would ensure that reading becomes their hobby, understand that good reading skills will improve their academic performance and make them better students, intend to continue reading on a regular basis and want to explore different genres.

Figure 4 depicts participants who considered reading to be a hobby before attending the intermediary programme, whilst Figure 5 depicts the participants who consider reading a hobby since attending the programme. In Figure 4, 6.41\%

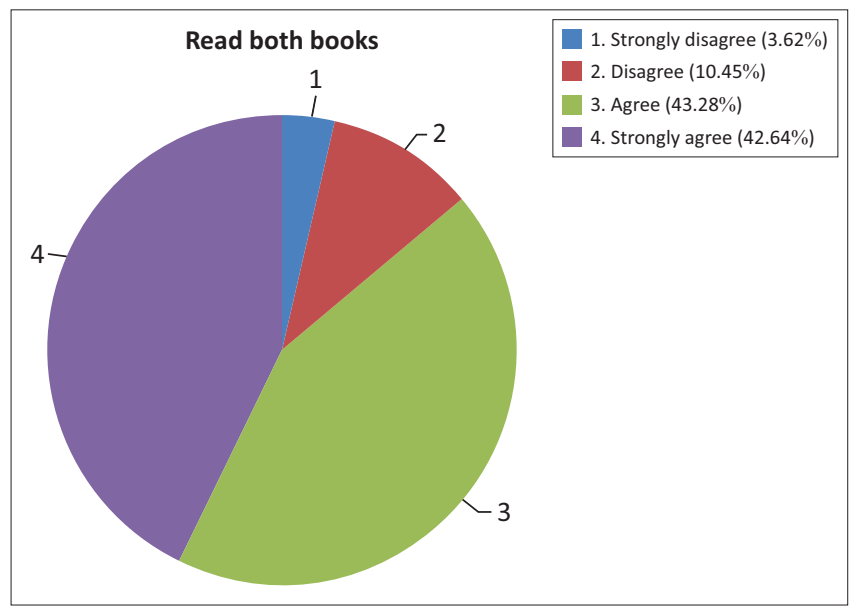

FIGURE 2: Read every book at school.

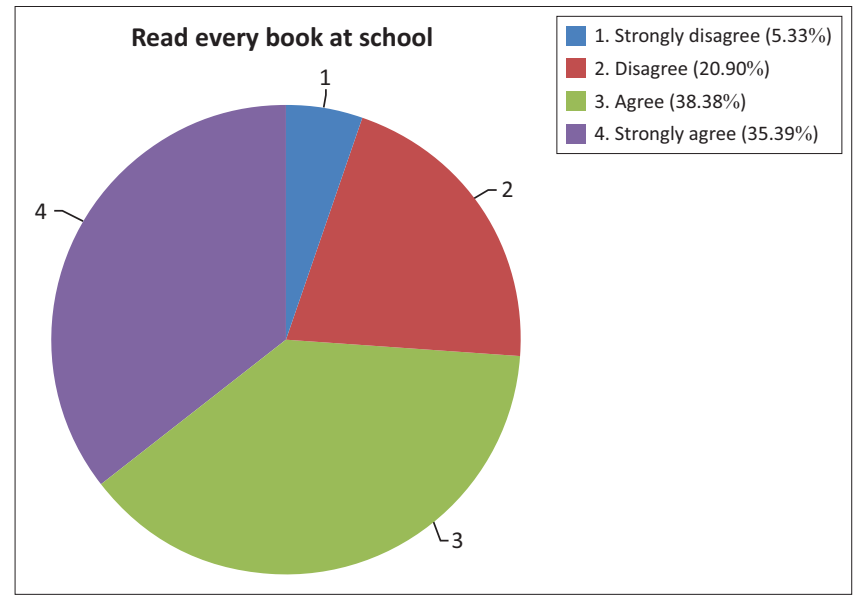

FIGURE 3: Read both books at Vaal University of Technology (VUT). strongly disagreed and $17.52 \%$ disagreed, whilst in Figure 5, $7.46 \%$ strong disagreed and $26.4 \%$ disagreed. This indicated a change in the behaviour of the participants from before attending the intermediary programme to subsequent to attending the programme.

Once the students complete the intermediary programme, they register for first-year courses, one of which is the EDL course, which is compulsory for all students. The aims, amongst others, are to assist students in overcoming English language and communication barriers and equip them with writing and communication skills. At the end of the year, one of the prerequisites for completion is a minimum speed of 300 words per minute. After registration, students are required to take a placement test. According to Walliman (2011:96), the most reliable representation of a population is through probability sampling techniques and random methods are used to select the sample. The sample should be a reliable representation of the entire population. Because of the large number of students who undertook the placement tests for EDL $(N=3465)$, simple random sampling was used to select the results of 40 students who attended the intermediary programme and these were compared with a random sample of 40 students who did not attend the intermediary programme but registered directly for the EDL course. The results reflect that the students who completed the intermediary programme did much better than those who did not attend the intermediary programme, as is evident from Figure 6 and Figure 7.

When the overall averages of these groups are compared, it is evident that the students who participated in the intermediary programme performed much better $(77 \%$ mean) than those who did not attend the intermediary programme, but applied directly to the EDL programme (66\% mean). Figure 8 illustrates this comparison.

\section{Perceptions on the development of reading skills through the intermediary programme}

Section E of the questionnaire was designed to ascertain whether the participants believed that the intermediary programme had developed their reading skills and they were required to answer on a dichotomous scale $(1=$ yes and $2=$ no) followed by the reason for their answer. Walliman (2011:71) states that the emotions, feelings, beliefs and judgements, which people have, can only be described in words. The open-ended question in Section E was analysed to discover themes and trends in the data.

TABLE 5: Future intentions $(N=465)$.

\begin{tabular}{|c|c|c|c|c|c|c|}
\hline Since attending, I ... & $\%$ Strongly disagree & $\%$ Disagree & $\%$ Agree & $\%$ Strongly agree & M & SD \\
\hline Have discovered genres that I enjoy & 5.5 & 19.2 & 46.3 & 29 & 2.98 & 0.842 \\
\hline Intend to ensure that reading becomes my hobby & 6.4 & 17.5 & 47.5 & 28.4 & 2.98 & 0.846 \\
\hline $\begin{array}{l}\text { Understand that good reading skills will improve my academic performance } \\
\text { and make me a better student }\end{array}$ & 2.13 & 1.71 & 27.72 & 68.44 & 1.53 & 0.833 \\
\hline Intend to continue reading on a regular basis & 4.7 & 11.3 & 48.4 & 35.6 & 3.14 & 0.798 \\
\hline Want to explore different genres & 5.5 & 9.6 & 52.5 & 32.4 & 3.12 & 0.787 \\
\hline
\end{tabular}

SD, standard 
Table 6 reflects the results of the question in Section E on whether the participants believe that the intermediary programme played a part in developing their reading skills. It can be seen that of the 469 participants, one of the

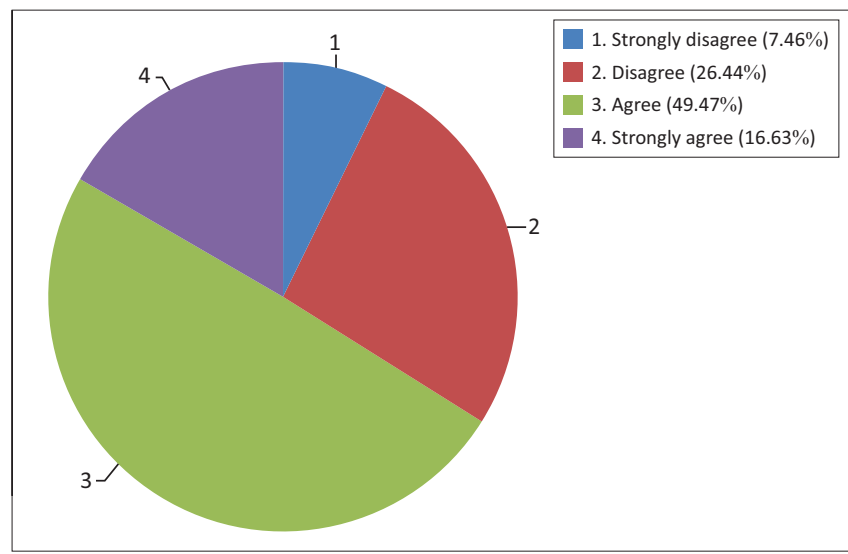

FIGURE 4: Participants who considered reading a hobby before attending the intermediary programme.

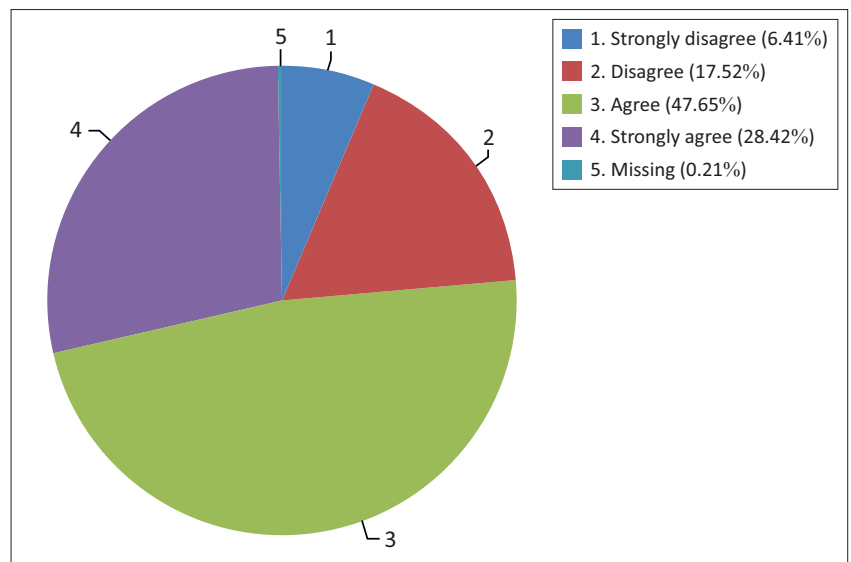

FIGURE 5: Participants who consider reading a hobby subsequent to attending the intermediate programme. participants declined to answer, 309 participants (84.9\%) believed that the intermediary programme developed their reading skills and 70 participants $(14.9 \%)$ did not believe that there had been a change in their reading skills.

Owing to the size of the study, it is not possible to include all the reasons supplied by the participants for their belief in the development of readings skills. However, some of the reasons and emerging themes are included in the next section.

\section{Improved vocabulary and reading speed and understanding benefits}

A number of participants indicated that they believed their vocabulary and/or reading speed had increased and that they had gained an understanding of the benefits of reading whilst attending the programme:

'I have developed a good reading skills and it also improved my vocabulary'.

'It taught me to use a dictionary regularly'.

'It does not only improve our reading skill but also teaches us new words and vocabulary'.

'Because for the first time in my life I managed to finish a whole book and learned new words out of the 2 books'.

'I was slow when it came to reading but after reading every day my speed of reading improved and my vocabulary is expanding'.

'Because it improved my reading skills which means my studying also improved and my marks changed for the better'.

General enjoyment was another emerging theme from the study and participants indicated this with the following comments:

'It helped me cope with the workload so reading was an escape route for $\mathrm{me}^{\prime}$.

'By first forcing me to read it gradually introduced me to a state where I wanted to read more'.

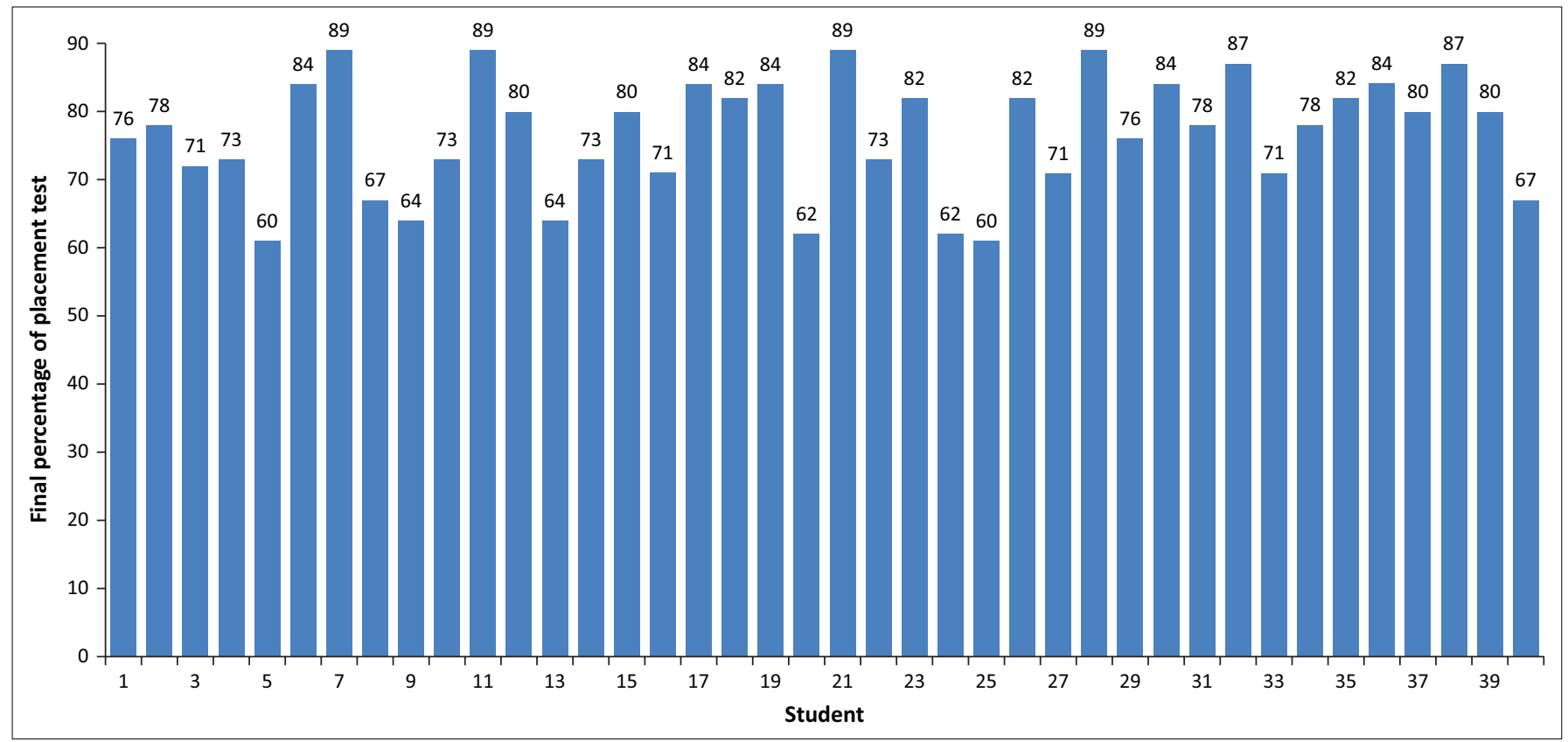

FIGURE 6: Placement test results for intermediary programme students. 


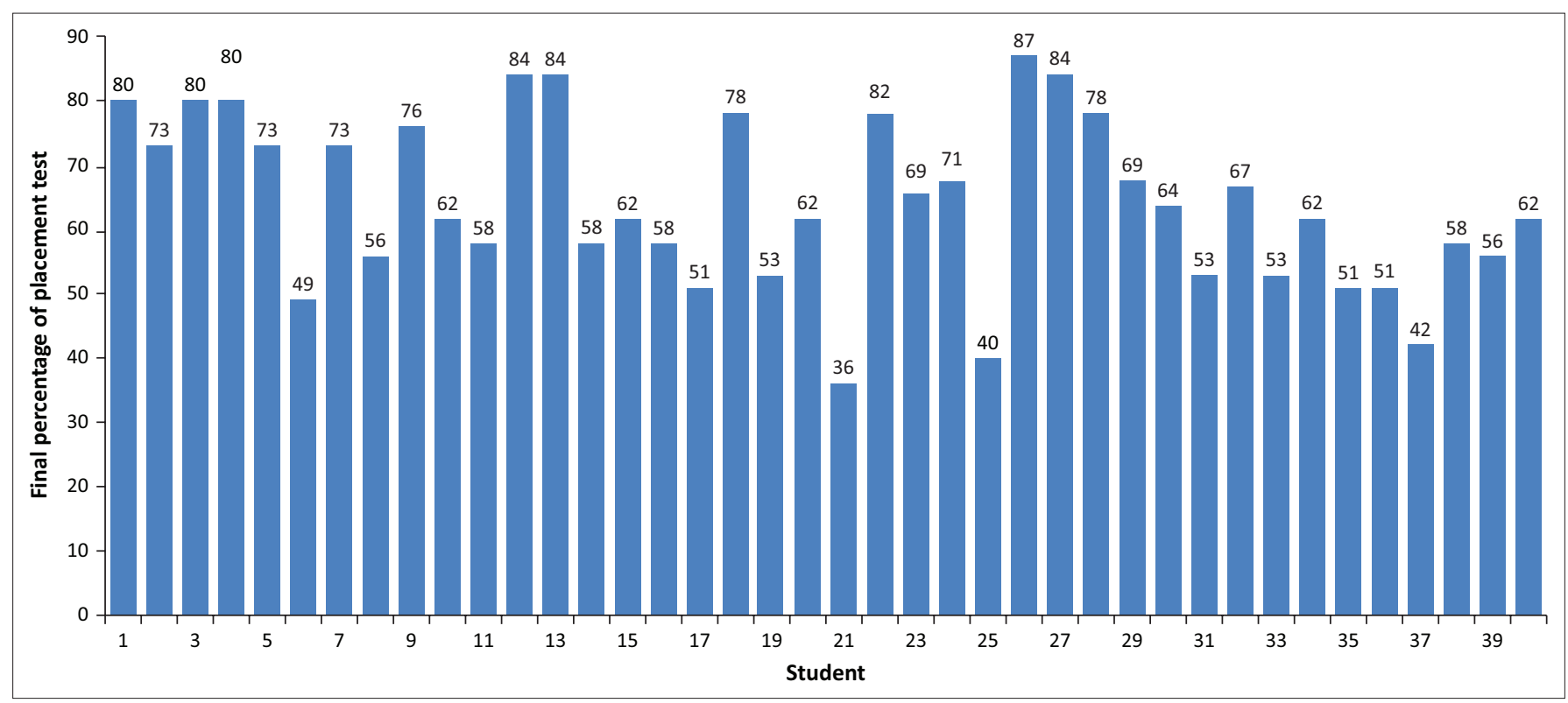

FIGURE 7: Placement test results for direct English distance learning (EDL) students.

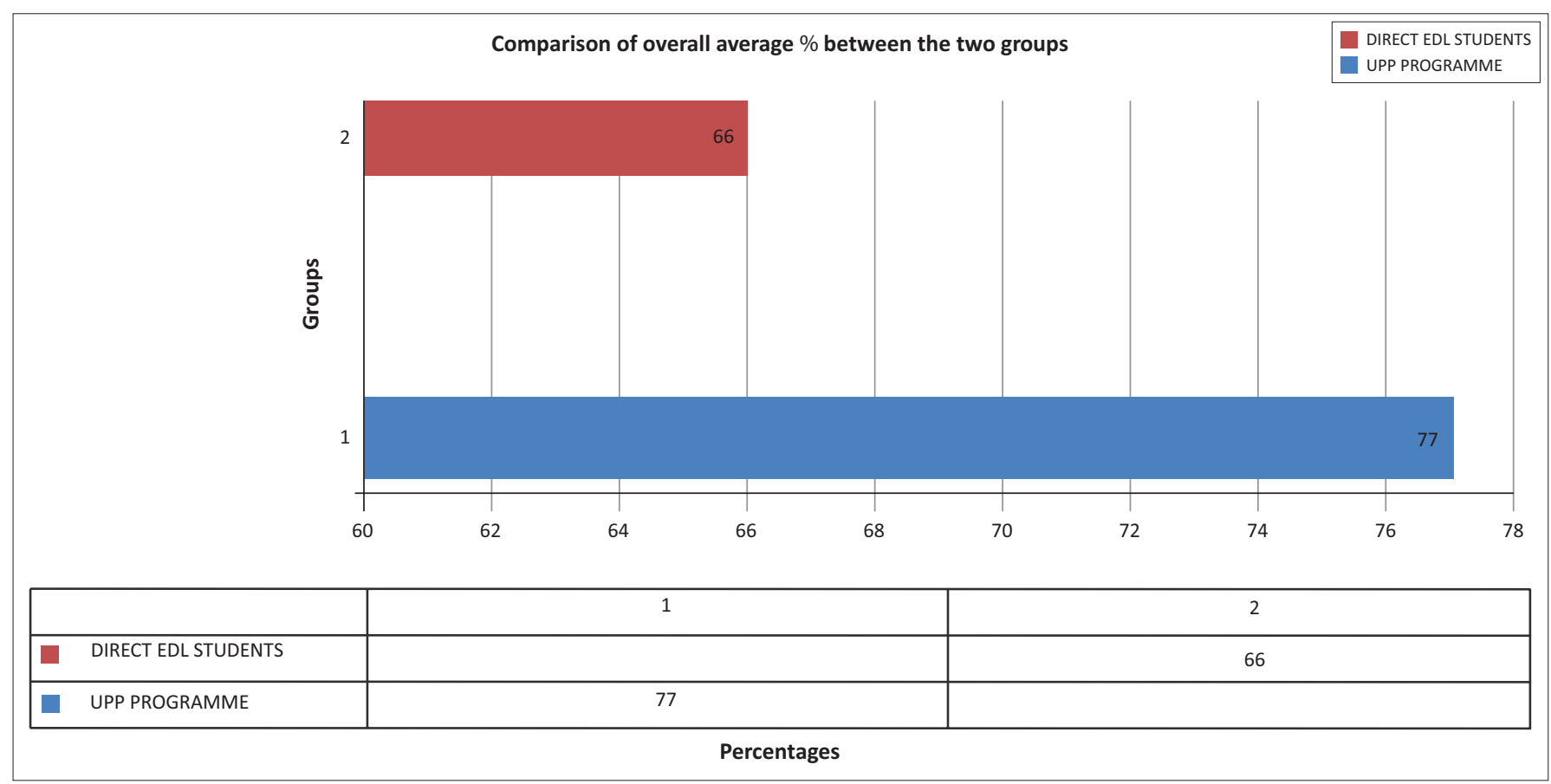

FIGURE 8: Comparative results of placement test results for EDL.

TABLE 6: The development of reading skills as perceived by participants.

\begin{tabular}{llcccc}
\hline Variable & & $\boldsymbol{f}$ & $\mathbf{\%}$ & Valid \% & Cumulative \% \\
\hline Valid & Yes & 398 & 84.9 & 85 & 85 \\
& No & 70 & 14.9 & 15 & 100 \\
& Total & 468 & 99.8 & 100 & - \\
Missing & System & 1 & 0.2 & - & - \\
\hline Total & & $\mathbf{4 6 9}$ & $\mathbf{1 0 0}$ & - & - \\
\hline
\end{tabular}

'The language programme "forced" me to read two books, which I really didn't believe I'd enjoy but found out that reading is fun and enjoyable'.

'Because I used to read only when told to do so by my lecture or teacher, but this days I even read on my own for fun'.

'I never used to read before, but realised how much I have learned, even when I thought I wouldn' $t^{\prime}$.
Discovering new genres and developing an interest: A surprising number of participants indicated that they had developed an interest in reading because of the programme:

'Because I can now sit and read books in a library'.

'Because I have improved on reading skills and gaining confidence and I enjoyed each and every moment'.

'I would usually skip chapters of a book to get to know the end of it, but not anymore'.

'It increased my reading ability, concentration span, improved my vocabulary and I also learned real life lesson'.

'Because having finished the two books in under a month made me realise that finishing a book is possible'.

'The programme has helped me a lot because reading is the key to success for me to succeed I must read'. 
These comments generally indicate that the programme fostered a change in the attitude towards reading of many students and that they were motivated to continue reading in the future.

The participants who disagreed with whether the intermediary language programme developed their reading skills stated that they either did not fully participate in the programme or believed that their skills did not need improvement, as indicated by the following comments:

\section{Did not participate fully in the programme:}

'I personally did not do much reading but I think it helped some people'.

'I was taught how to read from a young age. Reading at varsity was a waste of time'.

\section{Believed skills did not need improvement:}

'Because I've been reading books from high school and I was always motivated to read more. It is not anything new that I've been taught before'.

'I am a fluent reader'.

'Because before I joined this programme I was always a good reader'.

\section{Discussion}

Through the research article, the results indicate that of the 469 participants in this study, the majority $(84.9 \%)$ perceived there had been a change in their reading skills and only a small number $(14.9 \%)$ believed that there had not been a change in their reading skills. Furthermore, many participants plan to make reading their hobby (75.9\%) and when asked if they understand that good reading skills will improve their academic performance and make them better students, 96.1\% agreed, whilst only $6.4 \%$ disagreed. These figures are a clear indication of the substantial benefits from the programme, with students developing an enjoyment and enthusiasm about the reading. This leads to an improved attitude in students towards reading and a change in reading behaviour.

Lewin (2005) posits that the ability to read complex material is one of the major predictors of success in HE. Texts at tertiary level are much more complex and require the utilisation of sophisticated reading strategies. Moreover, L2 learners have added problems. Weak reading levels have serious implications on students' academic performance self-esteem and their ability to follow written instructions.

As stated by Bamford and Day (1997:7) in order to become good readers, students need to read large quantities of material. The aim of the intermediary programme is to encourage and promote reading in learners and to develop the skills of students that are required to achieve success in a tertiary institution; in doing so, students are provided with the valuable resources and knowledge to excel in their chosen disciplines.

\section{Conclusions, recommendations and limitations}

A limitation to the study is that within a diverse South African context the results from this study cannot be generalised to other universities, as there may be immense differences such as socio-economic status and cultural demographics of students. The male to female ratio in this study was fairly balanced but this study did not examine the differences between male and female perceptions or attitudes towards reading; this could be investigated further. It is also recommended that future studies include a benchmark test before the commencement of the programme and a test after completion of the programme. This would be beneficial for future studies because the statistical evidence of a before and after test could be used to compare participants' perceptions about actual achievements.

The researchers recommend the continuation of the reading module in the intermediary programme at the VUT. This recommendation is supported by the positive feedback received from the students and motivated by a review of reading research (Pretorius 2000; Lewin 2005) which indicates that students benefit from the explicit teaching of reading. An additional factor is the comparison of the data obtained from the placement tests for the EDL course, which indicates that students who completed the intermediary programme performed better than the students who did not attend the programme.

It is hoped that the research article will serve as a catalyst for institutions to seriously consider initiating similar programmes (Pretorius 2002) or recognise the value of reading programmes and the benefits gained by students.

\section{Acknowledgements Competing interests}

The authors declare that they have no financial or personal relationships which may have inappropriately influenced them in writing this article.

\section{Authors' contributions}

L.S. and E.S. contributed equally to the writing of this article.

\section{References}

Abramson, J.E., 2004, 'Reading. Essential life skills in 21st century', U.S, Mayor Newspaper, 13 September, 2004, viewed 05 January 2015, from http//www. usmayors.ord/usmayornewspaper/documents/09.13.04/Abramson.asp

Aina, J.K., Ogundele, A.G. \& Olanipekun, S.S., 2013, 'Students' proficiency in English language relationship with academic performance in science and technical education', American Journal of Educational Research 1(9), 355-358.

Akabuike, I.G., 2012, 'Reading habits of undergraduates and their academic performances: Issues and perspectives', African Research Review 6(2), 246-257.

Akarsu, O. \& Harputlu, L., 2014, 'Perceptions of EFL students toward academic reading', The Reading Matrix 14(1), 61-75.

Bamford, J. \& Day, R.R., 1997, 'Extensive reading: What is it? Why bother?', The Language Teacher 21(5), 6-8, 12. 
Bereiter, C. \& Scardamalia, M., 1987, The psychology of written composition, Lawrence Erlbaum Associates, Hillsdale.

Bernhardt, E.B., 1991, Reading development in a second language, Ablex, Norwood.

Bharuthram, S., 2012, 'Making a case for the teaching of reading across the curriculum in higher education', A Journal of Education 32(2), 205-214.

Bodendorf, F. \& Swain, P.H., 2001, 'Virtual universities in engineering education', The International Journal of Engineering Education 17(2), 102-107.

Butler, G., 2013, 'Discipline-specific versus generic academic literacy intervention for university education: An issue of impact?', Journal for Language Teaching 47(2), 71-88.

Carson, J. \& Leki, I., 1993, Reading in the composition classroom: Second language perspective, Heinle \& Heinle, Boston.

Carter, K., 2010, 'The effects of a reading intervention on first and second language English medium learners', M. Ed dissertation, University of the Witwatersrand, Johannesburg.

Day, R.R., Omura, C. \& Hiramatsu, M., 1991, 'Incidental EFL vocabulary learning and reading', Reading in a Foreign Language 7(2), 541-551.

Denscombe, M., 2010, The good research guide: For small-scale social research projects, McGraw-Hill International, Berkshire.

Dreyer, C. \& Kopper, M., 2004, 'An analysis of the reading profiles of first-year students at Potchefstroom University: A cross-sectional study and a case study', South African Journal of Education 24(1), 95-103.

Droop, M. \& Verhoeven, L., 2003, 'Language proficiency and reading ability in first- and second-language learners', Reading Research Quarterly 38, 78-103.

Grabe, W., 1991, 'Current developments in second language reading research', TESOL Quarterly 25, 375-406.

Gupta, S.L, 2011, Marketing research, Excel Books, New Delhi.

Hair, J.F., Jr., Bush, R. \& Orinau, D., 2008, Marketing research, 2nd edn., McGraw-Hill, New York.

Hulstijn, J.H., 1992, 'Retention of inferred and given word meanings: Experiments in incidental vocabulary learning', in P.J. Arnaud \& H. Bejoint (eds.), Vocabulary and applied linguistics, pp. 113-124, Macmillan, London.

Kannan, R., 2009, 'Difficulties in learning English as a second language', ESP World 5(26) 8 , viewed 8 January 2015, from http://wwwl.esp-world.info/Articles26/Original/ 8, viewed 8 anuary 2015, from http://wwwl.esp-world.info/Articles26/Original/

Kolawole, C.O.O., 2009, 'The state of reading in selected secondary schools in Oyo State, Nigeria', African Research Review 3(1), 388-398.

Lewin, T., 2005, 'Many going to college aren't ready, report finds', New York Times, viewed 19 January 2015, from http://query.nytimes.com/

Lukhele, B.B.S., 2013, 'Exploring relationships between reading attitudes, reading ability and academic performance amongst primary teacher trainees in Swaziland' Reading \& Writing 4(1), 1-8.

Maphosa, C., 2014, 'Towards a mainstream curriculum embedded student academic development programme in South African universities', International Journal of Educational Sciences 6(1), 11-18.
Melby-Lervåg, M. \& Lervåg, A., 2013, 'Reading comprehension and its underlying components in second-language learners: A meta-analysis of studies comparing first- and second-language learners', American Psychological Association 140(2) first- and $409-433$.

Nunnally, J.C., 1978, Psychometric theory, McGraw Hill, New York.

Palani, K.K., 2012, 'Promoting reading habits and creating literate society', International Refereed Research Journal 3(2), 90-94.

Papashane, M. \& Hlalele, D., 2014, 'Academic literacy: A critical cognitive catalyst towards the creation of sustainable learning ecologies in higher education', Mediterranean Journal of Social Sciences 5(10), 661-671.

Pitts, M., White, H. \& Krashen, S., 1989, 'Acquiring second language vocabulary through reading', Reading in a Foreign Language 5(2), 271-275.

Pretorius, E.J., 2000, 'Reading and the Unisa student: Is academic performance related to reading ability?', Progressio 22(2), 35-48.

Pretorius E.J., 2002, 'Reading ability and academic performance in South Africa: Are we fiddling while Rome is burning?', Language Matters 33, 69-196.

Rimensberger, N., 2014, 'Reading is very important, but ...: Taking stock of South African student teachers' reading habits', Reading \& Writing 5(1), 1-9.

Robatjazi, M.A., 2008, 'Language education: Intercultural communicative competence and curriculum', Glossa 3(2), 245-265.

Seitz, L., 2010, 'Student attitudes toward reading: A case study', Journal of Inquiry \& Action in Education 3(2), 30-44.

Stanovich, K.E., 1986, 'Matthew effects in reading: Some consequences of individual differences in the acquisition of literacy', Reading Research Quarterly 22, 360-407.

Sternglass, M.S., 1988, The presence of thought: Introspective accounts of reading and writing. Advances in discourse processes, Ablex Publishing Corporation, New York.

Sutherland, T., 2009, 'A curriculum framework for an introductory programme in the National Diploma: Engineering at the Vaal University of Technology', PhD thesis, Stellenbosch University.

Sutherland, T. \& Brits, M.M., 2009, Short course academic learning programmes policy, Vaal University of Technology, Vanderbijlpark.

Tien, C.-Y., 2015, 'A large-scale study on extensive reading program for non-English majors: Factors and attitudes', Internal Journal of Applied Linguists \& English Literature 4(4), 46-54.

Van Rooy, B. \& Coetzee-Van Rooy, S., 2015, 'The language issue and academic performance at a South African University', Southern African Linguistics and Applied Language Studies 33(1), 31-46.

Walliman, N., 2011, Research methods. The basics, Taylor \& Francis e-Library, viewed 20 December 2014, from http://uni.delf.pro/uploads/7/1/0/7/7107980/ research_methods_the_basics.pdf

Weideman, A.J., 2003, Academic literacy: Prepare to learn, Van Schaik, Pretoria.

Wiid, J. \& Diggines, C., 2013, Marketing research, 2nd edn., Juta, Cape Town.

Willis, J., Stephens, E. \& Matthew, K., 1996, Technology, reading and language arts, Allyn \& Bacon, Boston. 